\title{
In vitro effect of Levamisole on Rainbow Trout (Oncorhynchus mykiss) peripheral blood mononuclear cells
}

\section{Efecto in vitro del levamisol sobre las celulas mononucleares de la sangre periférica de trucha arcoíris (Oncorhynchus mykiss)}

\author{
Leonardo A. Gómez ${ }^{1}$, Raul A. Cortes ${ }^{2} \&$ Carlos T. Smith ${ }^{1, *}$ \\ ${ }^{1}$ Department of Microbiology, Faculty of Biological Sciences, University of Concepción, Concepción, Chile. P. O. Box 160-C, \\ Concepción, Chile. \\ 2Department of Fish Physiology and Biotechnology, Instituto de Acuicultura de Torre de la Sal (IATS), Consejo Superior de \\ Investigaciones Científicas (CSIC), Castellon, Spain. \\ *csmith@udec.cl, Telephone: 56 (41) 220 4287, Fax: 56 (41) 2245975
}

\begin{abstract}
The in vitro effect of levamisole $(1,10$ and $100 \mu \mathrm{g} / \mathrm{ml})$ on cells of the innate immune response of rainbow trout (Oncorhynchus mykiss) was studied, particularly the activity of natural cytotoxic cells and macrophages present in peripheral blood. Levamisole effect on natural cytotoxic cells was evaluated by their capacity to lyse HL-60 tumor cells while activity of macrophages was evaluated measuring production of reactive oxygen species and nitric oxide. Results indicate that natural cytotoxic cells activity was significantly increased by $1 \mu \mathrm{g} / \mathrm{ml}$ levamisole and that higher doses had no effect. On the other hand, reactive oxygen species and nitric oxide production by macrophages was not increased by any of the levamisole doses used and that the higher dose $(100 \mu \mathrm{g} / \mathrm{ml})$ induced a significant decrease of nitric oxide levels, which might be deleterious for the defensive response of these fish.
\end{abstract}

KEYworDS: Innate immunity; reactive oxygen species; ROS; nitric oxide.

\begin{abstract}
RESUMEN
Se estudió el efecto in vitro del levamisol $(1,10$ y $100 \mu \mathrm{g} / \mathrm{ml})$ sobre células de la respuesta inmune innata de trucha arcoíris (Oncorhynchus mykiss), particularmente la actividad de las células citotóxicas naturales y de los macrófagos presentes en sangre periférica. El efecto del levamisol sobre las células citotóxicas naturales fue evaluado mediante su capacidad para lisar células tumorales HL-60, mientras que la actividad de los macrófagos fue evaluado mediante la producción de especies reactivas del oxígeno y de óxido nítrico. Los resultados indican que la actividad de las células citotóxicas naturales fue incrementada significativamente por $1 \mu \mathrm{g} / \mathrm{ml}$ levamisol mientras que dosis mayores no produjeron este efecto. Por otro lado, la producción de especies reactivas del oxígeno y de óxido nítrico por los macrófagos no fue incrementada por ninguna de las dosis usadas, sin embargo dosis de $100 \mu \mathrm{g} / \mathrm{ml}$ indujeron una disminución significativa en los niveles de óxido nítrico, lo cual podría ser deletéreo para la respuesta defensiva de estos peces.
\end{abstract}

Palabras claves: Inmunidad innata; especies reactivas del oxígeno; ROS; óxido nítrico.

\section{INTRODUCTION}

Immunity against "foreignness" appeared early in evolution. Innate immunity, characterized as non-specific, is the first defense strategy and the most widely distributed and present in plants, invertebrates and vertebrates (Heine 2008). With the appearance of the first vertebrates, particularly gnathostomes, a new defensive strategy, the acquired or adaptive immune response (specific and with memory), acting jointly and coordinately with the innate response, appeared (Flajnik \& Du Pasquier 2004; Cooper \& Alder
2006). Thus, the adaptive immune response is present in most fish and all the rest of vertebrates and, therefore, fish are a key group for comparative studies to unravel the evolution of adaptive immunity (Plouffe et al. 2005).

Fish immunity is dependent on innate and adaptive (or acquired) responses (Secombes 1996). Innate immunity, being the first defensive line against microorganisms, is fundamental to avoid infectious diseases (Plouffe et al. 2005). Among the cellular components of innate immunity we can include natural cytotoxic cells (NCCs), functionally 
homologous to natural killer cells (NK) of mammals (Evans \& Jaso-Friedmann 1992; Praveen et al. 2006). One of the main functions of NCCs is to eliminate, without the requirement of a previous contact or recognition, intracellularly infected or transformed cells by lysing them or inducing their apoptosis (Praveen et al. 2006). Other important effectors of the innate response in fish are macrophages (Secombes 1996). Macrophages destroy pathogenic microorganisms by several mechanisms, including phagocytosis and production of reactive oxygen species (ROS) and nitric oxide (NO) (Secombes 1996; Lundén et al. 2002).

The activity of both cell populations (NCCs and macrophages) can be enhanced by a series of compounds with immnunostimulatory properties. These compounds, being efficient to increase immunocompetency and resistance to infections, have been used in aquaculture, veterinary and human medicine (Sakai 1999). One of these immunostimulating compounds is levamisole (Kajita et al. 1990; Findlay \& Munday 2000; Ispir \& Yonar 2007). It is a synthetic compound originally used as an anti-helminthic livestock and later on its immunostimulating property was demonstrated, leading to its use with this second purpose in veterinary and human medicine (Sakai 1999). In the aquaculture industry, it is used to increase defensive responses in fish (Findlay \& Munday 2000; Ispir \& Yonar 2007). In vivo results have shown its positive effect on the innate and adaptive responses (Cuesta et al. 2002; Kumari \& Sahoo 2006; Ispir \& Yonar 2007; Maqsood et al. 2009).

Hence, the in vivo immunostimulating effect of levamisole has been widely studied. Nevertheless, in vitro studies in fish and other animals have shown that this compound is immunosuppressive at high doses, negatively affecting the activity of some immunecompetent cells (Siwicki et al. 1990; Mulero et al. 1998; Li et al. 2004). For this reason, the purpose of this study was to evaluate the in vitro effect of different doses of levamisole on the activity of natural cytotoxic cells (NCCs) and peripheral blood macrophages, important components of the innate immune response in rainbow trout.

\section{MATERIALS AND METHODS}

FISH AND BLOOD SAMPLES

Apparently healthy 10 rainbow trouts (Oncorhynchus mykiss Walbaum 1792) of both sexes per group, ranging from 180 to $210 \mathrm{~g}$, were kept at the "Salmones Pangue" pisciculture (Bio Bío Region, Chile) during the summer, under normal conditions of culture. Blood samples were obtained by caudal vein puncture using heparinized syringes after animals were anesthetized with $15 \mathrm{ml}$ of $20 \%$ benzocaine (Veterquímica,
Santiago, Chile) in 1001 of water. Blood was transported, at $4^{\circ} \mathrm{C}$, to the Laboratory of Immunology, Department of Microbiology, Faculty of Biological Sciences, University of Concepción (Concepción, Chile) arriving in not more than $1 \mathrm{~h}$ after been drawn.

ISOLATION AND CULTURE OF MONONUCLEAR CELLS

Since a good source of NCCs and macrophages are the peripheral blood mononuclear cells (PBMCs), peripheral blood was centrifuged at $500 \mathrm{x}$ g during $30 \mathrm{~min}$ in ficollhypaque (density $1.077 \mathrm{~g} / \mathrm{ml}$ ) (Sigma Diagnostics, St. Louis., MO., USA) to separate the PBMCs (Greenlee \& Ristow 1992). After washing three times in sterile saline solution, the viability of PBMCs was assessed using $0.4 \%$ trypan blue (Sigma Chemical Co, St Louis MO, USA). Cellular viability exceeded $95 \%$ in all samples. PBMCs were finally resuspended at a concentration of $1 \times 10^{6}$ viable cells $/ \mathrm{ml}$ in RPMI 1640 medium (Gibco BRL, Grand Island NY, USA) supplemented with $10 \%$ fetal calf serum (FCS), $100 \mathrm{Ul} /$ $\mathrm{ml}$ penicillin and $120 \mu \mathrm{g} / \mathrm{ml}$ streptomycin (Sigma Aldrich Inc, St. Louis, MO, USA). Experimental groups received levamisole $\{(\mathrm{L}[-]-2,3,5,6-$ Tetrahidro-6-phenyllimidazo [2,1-b]thiazole) Hydrochloride\} (Sigma Chemical Co., St. Louis, MO. USA) at final doses of 1,10 or $100 \mu \mathrm{g} / \mathrm{ml}$ and were cultured for $24 \mathrm{~h}$ in 96 wells microtiter plates at $18^{\circ} \mathrm{C}$. Controls lacked levamisole.

ACTIVITY OF NONSPECIFIC CYTOTOXIC CELLS (NCCs)

After $24 \mathrm{~h}$ of culture in the absence or in the presence of 1,10 or $100 \mu \mathrm{g} / \mathrm{ml}$ levamisole, natural cytotoxic activity was assessed co-culturing PBMCs, which includes NCCs (Greenlee \& Ristow 1992), with HL-60 tumor line cells (ATCC, Rockville, MD. USA). Characteristics of HL-60 cells, a myeloid cell line from a patient with promyelocytic leukemia, including morphology as observed by light and transmission electron microscopy, growth kinetics, karyotype, cell surface markers, tumor formation and others were described by Gallagher et al. (1979). To measure the lysis of the tumor cells by NCCs, HL-60 cells (kept in RPMI 1640 medium supplemented as above) were previously labeled with $0.036 \%$ w/v neutral red (Merck, Darmstadt, Germany) in PBS for 30 min at $37^{\circ} \mathrm{C}$, washed three times and adjusted to a concentration of $1 \times 10^{6}$ viable cells $/ \mathrm{ml}$ in RPMI 1640 supplemented as above. Effector PBMCs were mixed with HL-60 target cells at a 1:10 ratio and coincubated during $180 \mathrm{~min}$ at $15^{\circ} \mathrm{C}$. Cytotoxic activity was measured by neutral red release from HL-60 cells lysed by NCCs using a spectrophotometer at $540 \mathrm{~nm}$ (Parish \& Mullbacher 1983). Assays were done in triplicate.

Production of ROS AND NO By MACrophages

Reactive oxygen species (ROS) and nitric oxide (NO) produced by macrophages, cellular population included in the PBMCs, was measured. ROS produced after $24 \mathrm{~h}$ 
stimulation with 1,10 or $100 \mu \mathrm{g} / \mathrm{ml}$ levamisole and controls were measured as described by Anderson \& Siwicki (1993) with modifications. This method is based on the reduction of nitroblue tetrazoliun (NBT) by the superoxide anions to the colored compound formazan, which can be spectrophotometrically measured. Briefly, $100 \mu \mathrm{l}$ of the experimental and control cultures containing $1 \times 10^{6}$ $\mathrm{PBMCs} / \mathrm{ml}$ were incubated, in Eppendorf tubes, with 100 $\mu 10.1 \%$ NBT (Sigma Chemical Co., St. Louis., MO., USA) for $60 \mathrm{~min}$. Later on, $1 \mathrm{ml} \mathrm{N}$,N-dimethylformamide (Merck, Darmstadt, Germany) was added and the Eppendorf tubes centrifuged for $10 \mathrm{~min}$ at $100 \mathrm{x}$ g. Absorbance of the supernatant was measured at $620 \mathrm{~nm}$. Assays were done in triplicate.

Nitric oxide (NO) production after $24 \mathrm{~h}$ of culture in the presence of 1,10 or $100 \mu \mathrm{g} / \mathrm{ml}$ levamisole and controls was determined using a procedure modified from Walsh et al. (2006), based on detection of nitrite $\left(\mathrm{NO}_{2}^{-}\right)$derived from the nitric oxide (NO) by means of the Griess reagent (sulphanilamide, naphthylethylenediamine and phosphoric acid) (Sigma-Aldrich Co., St. Louis., MO., USA). Briefly, from the cell cultures $\left(1 \times 10^{6} \mathrm{PBMC} / \mathrm{ml}\right)$ treated with the different concentrations of levamisole, $200 \mu 1$ were obtained and centrifuged for $10 \mathrm{~min}$ at $100 \mathrm{xg}$ and $100 \mu \mathrm{l}$ of supernatant was collected. The supernatant was incubated for 10 min with $100 \mu 1$ de $1 \%$ sulphanilamide in $5 \%$ phosphoric acid, and $100 \mu \mathrm{l}$ of $0.1 \% \mathrm{~N}$-naphthylethylenediamine were then added and incubated for 30 additional min. Nitrite was assessed spectrophotometrically at $540 \mathrm{~nm}$ in the supernatant. Assays were done in triplicate.

\section{Statistical ANALYSis}

The effect of the different doses of levamisole on the natural cytotoxic activity and production of ROS and NO was determined using a one-way ANOVA and Tukey's test. Significant differences were considered those with a value of $p<0.05$.

\section{RESULTS}

\section{EFFECT OF LEVAMISOLE ON NCCs ACTIVITY}

Natural cytotoxic activity by NCCs was determined by lysis of HL-60 tumor cells. Results indicate that a dose of $1 \mu \mathrm{g} /$ $\mathrm{ml}$ significantly increases cytotoxic activity $(p=0.039)$, but higher doses, 10 or $100 \mu \mathrm{g} / \mathrm{ml}$, show results not significantly different from controls (Fig. 1).

EFFECT OF LEVAMISOLE ON MACROPHAGES ROS AND NO ACTIVITY Activity of macrophages was assessed by the production of ROS and NO after $24 \mathrm{~h}$ of incubation with levamisole. In this work performed in vitro, ROS production was not affected by any of the levamisole doses used (Fig. 2). On the other hand, in vitro levamisole effect on $\mathrm{NO}$ production shows that 1 or $10 \mu \mathrm{g} / \mathrm{ml}$ had no effect on NO production but $100 \mu \mathrm{g} / \mathrm{ml}$ induced a significant reduction in the production of this molecule ( $p=0.035$ ) (Fig. 3).

\section{DISCUSSION}

Levamisole is a synthetic compound with immunostimulatory properties (Sakai 1999). It has been reported that in salmonids, such as Salmo salar and Oncorhynchus mykiss, in vivo, it increases immunity (Kajita et al. 1990; Findlay \& Munday 2000; Ispir \& Yonar 2007). Nevertheless, some reports indicate that, in vitro, high doses of levamisole induce immunosuppression, especially on the antibody forming cells (AFCs), macrophages and ROS production

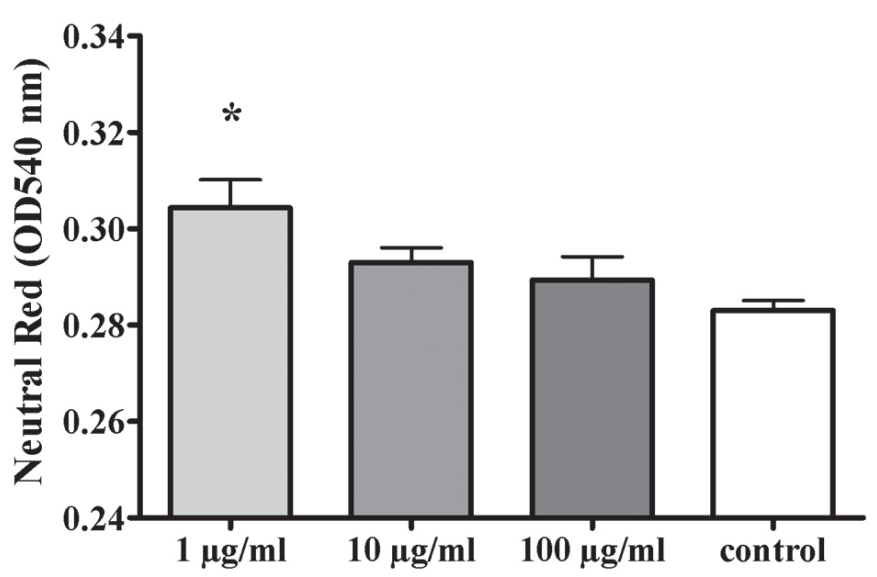

FIGURE 1. Effect of different doses of levamisole ( $24 \mathrm{~h}$ treatment) on the natural cytotoxic activity by trout peripheral blood mononuclear cells. Bars indicate mean \pm standard deviation. * Statistically significant difference $(p<0.05)$.

Figura 1. Efecto de diferentes dosis de levamisol (24 h de tratamiento) sobre la actividad citotóxica natural de las células mononucleares de sangre periférica de trucha. Las barras indican el promedio \pm desviación estándar. * Diferencias estadísticamente significativas $(\mathrm{p}<0,05)$. 


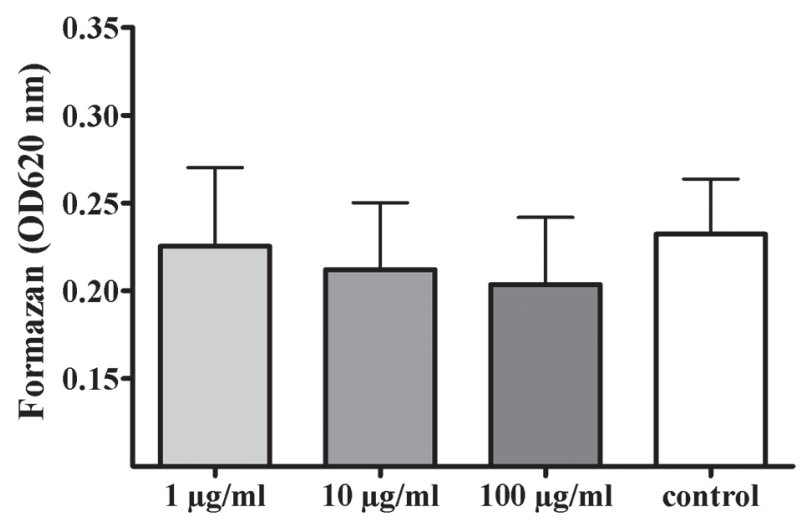

FIGURE 2. Effect of the different doses of levamisole ( $24 \mathrm{~h}$ treatment) on the production of reactive oxygen species (ROS) by trout peripheral blood mononuclear cells. Bars indicate mean \pm standard deviation.

FiguRa 2. Efecto de diferentes dosis de levamisol (24 h de tratamiento) sobre la producción de especies reactivas del oxígeno (ROS) por las células mononucleares de sangre periférica de trucha. Las barras indican el promedio \pm desviación estándar.

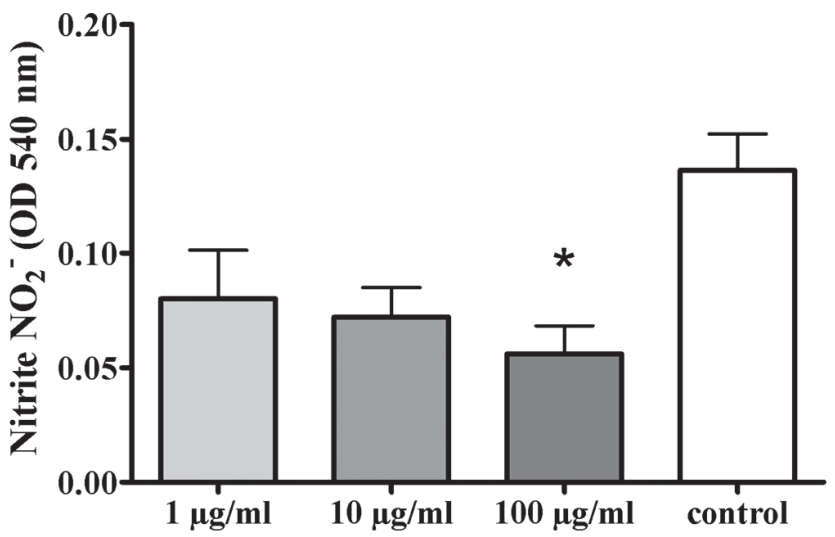

FiguRE 3. Effect of the different doses of levamisole ( $24 \mathrm{~h}$ treatment) on the production of nitric oxide $(\mathrm{NO})$ measured as $\left.\mathrm{Nitrite}^{-} \mathrm{NO}_{2}^{-}\right)$by trout peripheral blood mononuclear cells. Bars indicate mean \pm standard deviation. $*$ Statistically significant difference $(p<0.05)$.

Figura 3. Efecto de diferentes dosis de levamisol (24 h de tratamiento) sobre la producción de óxido nítrico (NO) medido como Nitrito $\left(\mathrm{NO}_{2}^{-}\right)$por las células mononucleares de sangre periférica de trucha. Las barras indican el promedio \pm desviación estándar. * Diferencias estadísticamente significativas $(p<0,05)$.

(Siwicki et al. 1990; Mulero et al. 1998; Li et al. 2004). For this reason, this work studies the in vitro effect of different levamisole doses on the activity of natural cytotoxic cells (NCCs) and macrophages, important components of the innate immune response, in trout.

Activity of NCCs was evaluated by their cytotoxic activity against HL-60 tumor cells while activity of macrophages was evaluated by the production of ROS and NO. NCCs and macrophages were obtained by isolation of PBMCs. PBMCs include lymphocytes, NCCs and macrophages (Yang et al. 1994). Nevertheless, given the conditions of the assays performed, only NCCs, and not other cellular populations, could exert cytotoxic activity and only macrophages present in the culture were able to produce ROS and NO for defensive purposes (Secombes 1996; Lundén et al. 2002).
The effect of levamisole on NCCs has been reported in various fish species (Findlay \& Munday 2000; Cuesta et al. 2002; Choi 2004), including rainbow trout (Kajita et al. 1990; Ispir \& Yonar 2007). Our results show a significant increase of trout NCCs activity stimulated in vitro for 24 h with $1 \mu \mathrm{g} / \mathrm{ml}$ levamisole (Fig. 1). These results are in agreement with those reported by Cuesta et al. (2002) for the gilthead seabream (Sparus aurata) and by Choi (2004) for the Japanese flounder (Paralichthys olivaceus) showing that in vitro levamisole doses ranging from 0.001 to $0.1 \mu \mathrm{g} / \mathrm{ml}$ (doses under the lowest used in this work) also significantly increased the activity of NCCs. Hence, the positive effect of low doses of levamisole on NCCs activity is confirmed in different species of teleosts. Furthermore, we can report that high doses of levamisole (up to $100 \mu \mathrm{g} / \mathrm{ml}$ ), which might be deleterious for other defensive functions, such as 
the antibody forming cells (AFCs), macrophages and ROS production (Siwicki et al. 1990; Mulero et al. 1998; Li et al. 2004), do no inhibit natural cytotoxic activity (Figure 1). In brief, considering the role played by NCCs in the defense of an organism, we can conclude that low doses of levamisole are favorable in the immune response against tumor cells and intracellular pathogens and that high doses would not negatively affect NCCs.

Besides evaluating the effect of levamisole on trout NCCs, we also studied its effect on macrophages, particularly on ROS and NO production by these cells. When evaluating the in vitro levamisole effect on ROS production by macrophages, contrary to what happened with NCCs activity (Figure 1), there was no ROS increase with any of the three doses used (Figure 2). Our results are similar to those reported by other authors, such as Mulero et al. (1998), reporting that in vitro doses below $1 \mu \mathrm{g} / \mathrm{ml}$ do not increase ROS production in the gilthead seabream (S. aurata). But, they showed a significant decrease in ROS production after $48 \mathrm{~h}$ of stimulation with $1 \mu \mathrm{g} / \mathrm{ml}$ levamisole, a time span not evaluated in this work. Also, Li et al. (2004) reported an in vitro decrease in ROS production in the hybrid striped bass (Morone chrysops and Morone saxatilis) after treatment with $1000 \mu \mathrm{g} / \mathrm{ml}$ levamisole for $24 \mathrm{~h}$, a tenfold increase if compared with the highest dose studied in this work. These results suggest that in vitro treatment with levamisole does not produce the same increase in ROS production by macrophages observed in vivo (Kumari \& Sahoo 2006; Ispir \& Yonar 2007).

In vertebrates in general, activated $\mathrm{T}$ lymphocytes produce a series of cytokines able to regulate the activity of NCCs and macrophages (Bird et al. 2006). Thus, we cannot discard that levamisole in vivo activates T lymphocytes which, in turn, exert their regulatory effect on NCCs and macrophages. In vitro work with PBMCs might not provide the same cellular interactions present in vivo, thus explaining the different results obtained when working in vivo or in vitro, that is to say the presence or absence, respectively, of ROS increase after levamisole stimulation.

We have been unable to find other reports evaluating nitric oxide (NO) production by teleost macrophages after levamisole stimulation. Our results indicate that levamisole doses of 1 and $10 \mu \mathrm{g} / \mathrm{ml}$ do not affect nitric oxide production, while $100 \mu \mathrm{g} / \mathrm{ml}$ significantly reduced production of this compound (Fig. 3). This suppression might be related to the already described negative effect of high in vitro levamisole doses on some parameters of the immune response (Siwicki et al. 1990; Mulero et al. 1998; Li et al. 2004).

Since in vivo low doses of levamisole exert a positive effect absent in in vitro experiments, we can support the idea that macrophages may not be the direct target for levamisole effect, but other immunocompetent cells might respond in vivo to levamisole and secrete cytokines which, in turn, will signal macrophages. Some reports suggest that $T$ lymphocytes might be targets for levamisole action (Tizard 2009). For this reason, it becomes necessary to determine if trout $\mathrm{T}$ lymphocytes in fact regulate the activity of NCCs and macrophages. If so, studies involving levamisole might help to comprehend the regulatory role of $\mathrm{T}$ lymphocytes on the activity of NCCs and macrophages, the interaction of immunocompetent cells in teleost fish and, therefore, to search ways to better stimulate the immune response of these animals against infectious diseases.

\section{ACKNOWLEDGEMENTS}

This work was supported in part by Grant 97.036.05-1, Dirección de Investigación, Universidad de Concepción. We are grateful to Mr. Ricardo Quiroz (owner of Salmones Pangue), who allowed us to perform the experiments at his premises.

\section{BIBLIOGRAPHY}

Anderson, D. \& Siwicki, A. 1993. Measuring the effects of contaminants on fish by haematological and serological methods. In: Modulators of fish immune responses (Eds. Stolen, J., Anderson, D., Zelikoff, S., Twerdok, L. \& S. Kaattari), pp. 95-118. SOS Publications, Fair Haven NJ.

Bird, S., Zou, J. \& Secombes, C. 2006. Advances in fish cytokine biology give clues to the evolution of a complex network. Current Pharmaceutical Design 12:3051-3069.

CHol, S. 2004. Levamisole enhances the natural cytotoxic cell activity of Japanese flounder (Paralichthys alivaceus) head kidney leukocytes. Korean Journal of Biological Science 8: 329-333.

Cooper, M. \& Alder, M. 2006. The evolution of adaptive immune systems. Cell 124:815-822.

Cuesta, A., Esteban, M. \& Meseguer, J. 2002. Levamisole is a potent enhancer of gilthead seabream natural cytotoxic activity. Veterinary Immunology and Immunophatology 89:169-174.

Evans, D. \& JASO-Friedmann, L. 1992. Nonspecific cytotoxic cell as effectors of immunity in fish. Annual Reviews of Fish Diseases 2:109-121.

Findlay, V. \& Munday, B. 2000. The immunomodulatory effects of levamisole on the nonspecific immune system of Atlantic salmon, Salmo salar L. Journal of Fish Disease 23:369-378.

Flajnik, M. \& Du Pasquier, L. 2004. Evolution of innate and adaptive immunity: can we draw a line?. Trends Immunology 25:640-644.

Gallagher, A., Collins, S., Trujillo, J., McCredie,K., Ahearn, M., Tsai, S., Metzgar, R., Aulakh, G., Ting, R., Ruscetti, F. \& GAllo, A. 1979. Characterization of the continuous, 
differentiating myeloid cell line (HL-60) from a patient with acute promyelocytic leukemia. Blood 54:713-733.

Greenlee, A. \& Ristow, S. 1992. Detection of apoptic killing by trout nonspecific cytotoxic cell using the DNA fragmentation assay and agarose gel electrophoresis. In: Techniques in fish immunology, Vol. 2 (Eds. Stolen, J., T. Fletcher, D. Anderson, S. Kaattari \& R. Rowley), pp. 97105. SOS Publications, Fair Haven NJ.

HeIne, H. 2008. Innate Immunity of Plants, Animals, and Humans. In: Nucleic Acids and Molecular Biology (Eds. Gross, H.J), pp. 241. Springer-Verlag Berlin.

IsPIR, U. \& YonAR, M. 2007. Effects of levamisole on phagocytic activity of rainbow trout (Oncorhynchus mykiss W.). Acta Veterinaria Brno 76:493-497.

KajtTa, Y., Sakai, M., Atsuta, S. \& Kobayashi, M. 1990. The immunomodulatory effects of levamisole on rainbow trout, Oncorhynchus mykiss. Fish Pathology 25:93-98.

Kumari, J. \& SAHOO, P. 2006. Dietary levamisole modulates the immune response and disease resistance of Asian catfish Clarias batrachus (Linnaeus). Aquaculture Research 37:500-509.

Li, P., WAng, X. \& Gatuin, D. 2004. Excessive dietary levamisole suppresses growth performance of hybrid striped bass, Morone chrysops, M. saxatilis, and elevated levamisole in vitro impairs macrophage function. Aquaculture Research 35:1380-1383.

LundÉN, T., LiLIUS, E. \& BYLUND, G. 2002. Respiratory burst activity of rainbow trout (Oncorhynchus mykiss) phagocytes is modulates by antimicrobial drugs. Aquaculture 207:203213.

MAQsood, S., SAmoon, M. \& Singh, P. 2009. Immunomodulatory and growth promoting effect of dietary levamisole in Cyprinus carpio fingerlings against the challenge of Aeromonas hydrophila. Turkish Journal of Fisheries and Aquatic Science 9:111-120.
Mulero, V., Esteban, M. \& Meseguer, J. 1998. In vitro levamisole fails to increase seabream (Sparus aurata L.) phagocyte functions. Fish and Shellfish Immunology 8:315-318.

PARISH, C. \& MüllbaCher, A. 1983. Automated colorimetric assay for $\mathrm{T}$ cell cytotoxicity. Journal of Immunology Methods 58:225-237.

Plouffe, D., Hanington, P., Walsh, J., Wilson, E. \& Belosevic, M. 2005. Comparison of select innate immune mechanisms of fish and mammals. Xenotransplantation 12:266-277.

Praveen, K., Leary, J., Evans, E. \& Jaso-Friedmann, L. 2006. Nonspecific cytotoxic cells of teleosts are armed with multiple granzymes and other components of the granule exocytosis pathway. Molecular Immunology 43:1152-1162.

SAKAI, M. 1999. Current research status of fish immunostimulants. Aquaculture 172:63-99.

Secombes, C. 1996. The nonspecific immune system: cellular defences. In: The fish immune system: organism, pathogen and environment (Eds. Iwama, G. \& Nakanishi, T.), pp. 63-103. Academic Press Ltd., London.

Siwicki, A., Anderson, D. \& Dixon, O. 1990. In vitro immunostimulation of rainbow trout (Oncorhynchus mykiss) spleen cells with levamisole. Develomental and Comparative Immunology 14:231-237.

TizARD, I. 2009. Drugs and other agents that affect the immune system. In: Veterinary Immunology (Eds. Tizan, I.R.), pp. 480-489. $8^{\text {th }}$ Edition, Saunders Elsevier.

Yang, K., Augustine, N., Shaio, M., Bohnsack, J. \& Hill, H. 1994. Effects of fibronectin on actin organization and respiratory burst activity in neutrophils, monocytes and macrophages. Journal of Cellular Physiology 158:347-353.

Walsh, C., Toranto, J., Gilliland, T., Noyes, D., Bodine, A. \& LuER, C. 2006. Nitric oxide production by nurse shark (Ginglymostoma cirratum) and clearnose skate (Raja eglanteria) peripheral blood leucocytes. Fish and Shellfish Immunology 20:40-46.

Recibido: 29.09.14

Aceptado: 25.08.15 